\title{
Scenario of Cause of Death at Government Hospital of Dhanusha District, Nepal
}

\author{
Krishna Deo Das ${ }^{1}$, Satyam Prakash ${ }^{2 *}$, Khushbu Yadav ${ }^{3}$ \\ ${ }^{1}$ Medical Officer, Janakpur Zonal Hospital \& Assistant Professor, Dept. of Community Medicine, Janaki Medical College, Janakpur, Nepal \\ ${ }^{2}$ Assistant Professor, Department of Biochemistry, Janaki Medical College Teaching Hospital, Janakpur, Nepal \\ ${ }^{3}$ Medical Microbiologist \& Lecturer, Krishna Medical Technical Research Center, Janakpur, Nepal
}

Submission: December 27, 2016; Published: March 30, 2017

"Corresponding author: Satyam Prakash, Assistant Professor, Department of Biochemistry, Janaki Medical College Teaching Hospital, Tribhuvan University, Janakpur-45600, Dhanusha, Nepal, Mobile: +977-9841603704; +977-9844405444, E-mail: sprakashy2424@gmail.com

\begin{abstract}
Background and Objectives: Births and deaths create vital basic data about a population group. Prompt and accurate certification of death is essential at it provides legal evidence of the fact, manner and causes of death either natural or unnatural. Cause of death is a popular method for illustrating the relative burden of cause-specific mortality statistics. Therefore, this study was designed to expose the cause of death at Government hospital of Dhanusha district, Nepal.
\end{abstract}

Methods: A retrospective study was carried out on 217 cases of death due to various reasons. Information regarding the name, age, address, way of committing suicide and place of death were taken from the inquest reports, hospital records, post-mortem records of Janakpur Zonal hospital. Frequent supervision and cross checklist of the filled form were performed to maximize the reliability and validity. The data were entered into computer and analysed by using SPSS 20.0 version and was considered statistically significant $\leq 0.05$ p-value.

Results: Most of the death cases were found due to poisoning (39\%). Male (62.67\%) was predominant than female (37.32\%) in total death. The highest number of death cases were found below 19 years due to drowning $(71.57 \%)$ followed by age group 20 -39 years due to poisoning (41.17\%). July to September (35.02\%) was the month when death occurred high. The association between age group and death due to poisoning was higher in between $0-39$ years with $62.35 \%$ and was statistically significant ( $\mathrm{p}=0.0001$ ).

Conclusion: Most of the death cases were found due to poisoning. Proper education of common people, cultivators about storage, handling, uses of pesticide and insecticide will help to reduce incidence of poisoning.

Keywords: Unnatural Death; Autopsy; Poisoning; Drowning; Significant

\section{Introduction}

Death either it is natural or unnatural, is a harsh reality of life. The debate surrounding the medical and legal definition of death is driven by a need to preserve medical resources and procure organs rather than by an honest scientific and philosophical inquiry about the meaning of life and death [1]. The unnatural and suspected deaths are subjected to medicolegal investigation. Prompt and accurate certification of death is essential at it provides legal evidence of the fact, manner and causes of death, thus enabling the death to be formally registered, the family can then make arrangements for disposal of the body [2].

Medical certification of causes of death is a popular method of presenting mortality statistics and is a useful means for illustrating the relative burden of cause of specific mortality. Medical expertise is crucial in death investigations. It begins with body examination and evidence collection at the scene and proceeds through history, physical examination, laboratory tests, and diagnosis. The key goal is to provide objective evidence of cause, timing, and manner of death for adjudication by the criminal justice system. Death investigation has been performed for centuries in all societies, although not always by medical professionals [3].

About 57 million deaths occur every year worldwide. Of them more than three fourths $(76.7 \%)$ is reported to occur in the developing countries. South East Asia contributes to about $22 \%$ of the total global death [4,5]. According to the official health statistics of Nepal, the health indicators have improved to a great extent during the last four decades. Nepal falls under the category of "high mortality" developing countries as categorized by WHO. Besides, WHO considers that the coverage of registration of death is far less than 25\% [5]. 
National indicators on cause of death might vary across various age groups, geo-ecological region, social groups, and from one to another district. There has been a remarkable longterm decline in mortality rates which is good sign of progress in the developing countries like Nepal. Public health programs are designed to achieve the goal of reducing the mortality from specific diseases, but there is lack of information on mortality pattern in the medical/health literature encompassing a total scenario. In Nepal, very few studies have been implicated in the specific causes of death in the country. So, it is troublesome to know the pattern and cause of death due to the dearth of information. There is no proper functioning system to measure the cause of death from different aspects. Hence, this study was designed to expose the cause of death at Government hospital of Dhanusha district, Nepal which will be helpful means on mortality statistics in formulation of National Health Policy in the country.

\section{Materials and Methods}

\section{Study design}

A retrospective hospital based study was conducted at Government Janakpur Zonal Hospital in collabration with Janaki Medical College Teaching Hospital, Janakpur, Nepal in 2016.

\section{Study population}

A total of 217 unnatural death cases due to various reasons registered during this period were consecutively enrolled in the study.

\section{Ethical consideration}

Ethical approval for the study was taken from Janaki Medical College Teaching Hospital and Janakpur Zonal Hospital, Janakpur.

\section{Data collection and processing}

Data collection was performed by the members of this research group and was cross checked by one another for any missed information. Cause of death were recorded from the statement of relatives, the inquest reports and confirmed by the autopsy. Unnatural death cases were included whereas natural death, death due to diseases or missed record data of death cases were excluded from the study

\section{Statistical analysis}

The computation of data was done with the help of Microsoft Excel and SPSS 20.0 version in tabular forms and observations were recorded and analyzed.

\section{Results}

\section{Pattern of Total Death cases}

A total of 217 death cases reported in Janakpur Zonal Hospital of which $39 \%, 15 \%, 8 \%, 26 \%, 1 \%, 7 \%$ and $4 \%$ were due to poisoning, drowning, current, hanging, thundering, fall from height and burn respectively. The results are shown in figure 1.

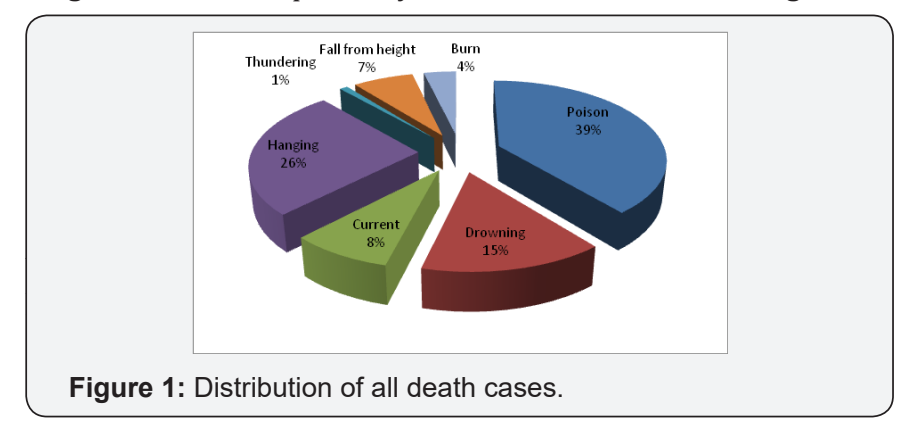

\section{Age and gender wise distribution of death cases}

Out of total death cases, $136(62.67 \%)$ were male and $81(37.32 \%)$ were female. The highest number of death cases were found in male than female below 19 years age group of $35.02 \%$ followed between 20-39 years with $34.56 \%$ and was statistically insignificant $(\mathrm{p}=0.416)$. The results are shown in Table 1.

Table 1: Pattern of age and gender wise distribution of total death cases.

\begin{tabular}{|c|c|c|c|c|}
\hline $\begin{array}{c}\text { Age Group } \\
\text { (yrs) }\end{array}$ & $\begin{array}{c}\text { Male No. } \\
(\mathbf{\%})\end{array}$ & $\begin{array}{c}\text { Female No. } \\
(\mathbf{\%})\end{array}$ & Total (\%) & p-value \\
\hline $0-19$ & $45(33.08)$ & $31(38.27)$ & $76(35.02)$ & \\
\hline $20-39$ & $43(31.61)$ & $32(39.50)$ & $75(34.56)$ & \\
\hline $40-59$ & $31(22.79)$ & $10(12.34)$ & $41(18.89)$ & \\
\hline $60-79$ & $15(11.02)$ & $08(9.87)$ & $23(10.59)$ & \\
\hline$>80$ & $02(1.47)$ & $00(00)$ & $02(0.92)$ & 0.416 \\
\hline Total & $136(62.67)$ & $81(37.32)$ & 217 & \\
\hline
\end{tabular}

\section{Gender wise distribution of death cases due to various reasons}

Most of the death cases were due to poisoning $85(39.17 \%)$ of which $46(33.82 \%)$ were male and $39(48.14 \%)$ were female followed by hanging $57(26.26 \%)$ of which $32(23.52 \%)$ were male and $25(30.86 \%)$ were female. The results are shown in Table 2.

Table 2: Frequency distribution of total death cases due to various reasons.

\begin{tabular}{|c|c|c|c|}
\hline Death Cases & Male (\%) & Female (\%) & Total (\%) \\
\hline Poison & $46(33.82)$ & $39(48.14)$ & $85(39.17)$ \\
\hline Drowning & $26(19.11)$ & $06(7.40)$ & $32(14.74)$ \\
\hline Current & $15(11.02)$ & $03(3.70)$ & $18(8.29)$ \\
\hline Hanging & $32(23.52)$ & $25(30.86)$ & $57(26.26)$ \\
\hline
\end{tabular}


Current Trends in Biomedical Engineering \& Biosciences

\begin{tabular}{|c|c|c|c|}
\hline Thundering & $02(1.47)$ & $00(00)$ & $02(0.92)$ \\
\hline Fall from height & $13(9.55)$ & $02(2.46)$ & $15(6.91)$ \\
\hline Burn & $2(1.47)$ & $06(7.40)$ & $08(3.68)$ \\
\hline Total & $136(62.67)$ & $81(37.32)$ & 217 \\
\hline
\end{tabular}

\section{Age wise distribution of death cases due to various reasons}

Table 3: Age wise distribution of total death cases.

\begin{tabular}{|c|c|c|c|c|c|c|c|c|}
\hline $\begin{array}{l}\text { Age group } \\
\text { (Yrs) }\end{array}$ & Poisoning & Drowning & Current & Hanging & Thundering & $\begin{array}{c}\text { Fall from } \\
\text { height }\end{array}$ & Burn & Total \\
\hline $0-19$ & 18(21.17) & $23(71.57)$ & 07 (38.88) & 19 (33.33) & $\begin{array}{c}01 \\
(50)\end{array}$ & $08(53.33)$ & $00(00)$ & $76(35.02)$ \\
\hline $20-39$ & $35(41.17)$ & 05(15.62) & 06 (33.33) & 22 (38.59) & $\begin{array}{c}01 \\
(50)\end{array}$ & $02(13.33)$ & $04(50)$ & $5(34.56)$ \\
\hline $40-59$ & $19(22.35)$ & 03(9.37) & $03(16.66)$ & $12(21.05)$ & $\begin{array}{c}00 \\
(00)\end{array}$ & $02(13.33)$ & $02(25)$ & 41 18.89) \\
\hline $60-79$ & 13(15.29) & 01(3.12) & 02 (11.11) & $\begin{array}{c}03 \\
(5.26)\end{array}$ & $\begin{array}{c}00 \\
(00)\end{array}$ & $02(13.33)$ & $02(25)$ & $23(10.59)$ \\
\hline$>80$ & $00(00)$ & $00(00)$ & $\begin{array}{c}00 \\
(00)\end{array}$ & $\begin{array}{c}01 \\
(1.75)\end{array}$ & $\begin{array}{c}00 \\
(00)\end{array}$ & $01(6.66)$ & $00(00)$ & $02(0.92)$ \\
\hline Total & 85(39.17) & $32(14.74)$ & 18(8.29) & $57(26.26)$ & $\begin{array}{c}02 \\
(0.921)\end{array}$ & $15(6.91)$ & $08(3.6)$ & 217 \\
\hline
\end{tabular}

Of total death cases, the highest number of death cases were reported in the age group below 19 years due to drowning $23(71.57 \%)$ followed by $20-39$ years due to poisoning $35(41.17 \%)$. The results are shown in Table 3.

\section{Month wise distribution of death cases}

The highest number of death cases were reported in July to September 76(35.02\%) followed by April to June 55(25.34\%) due to poisoning of $33(38.82 \%)$ and $24(28.23 \%)$ respectively. The results are shown in Table 4.

Table 4: Incidence of total death cases according to month wise.

\begin{tabular}{|c|c|c|c|c|c|c|c|c|}
\hline Months & $\begin{array}{c}\text { Poisoning } \\
(\%)\end{array}$ & $\begin{array}{c}\text { Drowning } \\
(\%)\end{array}$ & Current (\%) & $\begin{array}{c}\text { Hanging } \\
(\%)\end{array}$ & $\begin{array}{c}\text { Thundering } \\
(\%)\end{array}$ & $\begin{array}{c}\text { Fall from } \\
\text { height (\%) }\end{array}$ & Burn (\%) & Total (\%) \\
\hline Jan-Mar & $10(11.76)$ & $5(15.62)$ & $00(00)$ & $20(35.08)$ & $00(00)$ & $06(40)$ & $06(75)$ & $47(21.65)$ \\
\hline Apr-Jun & $24(28.23)$ & $06(18.75)$ & $07(38.88)$ & $13(22.80)$ & $00(00)$ & $04(26.66)$ & $01(12.5)$ & $55(25.34)$ \\
\hline Jul-Sep & $33(38.82)$ & $12(37.5)$ & $10(55.55)$ & $15(26.31)$ & $02(100)$ & $03(20)$ & $01(12.5)$ & $76(35.02)$ \\
\hline Oct-Dec & $18(21.17)$ & $09(28.12)$ & $01(5.55)$ & $09(15.78)$ & $00(00)$ & $02(13.33)$ & $00(00)$ & $39(17.97)$ \\
\hline Total & $85(39.17)$ & $32(14.74)$ & $18(8.29)$ & $57(26.26)$ & $02(0.92)$ & $15(6.91)$ & $08(3.68)$ & 217 \\
\hline
\end{tabular}

Table 5: Association of total death due to poisoning in relationship with age group.

\begin{tabular}{|c|c|c|c|c|}
\hline Age group (yrs) & Due to poison (\%) & Not due to poison (\%) & Total & 151 \\
\hline $0-39$ & $53(62.35)$ & $98(74.24)$ & 66 \\
\hline $40-79$ & $32(37.64)$ & $34(25.75)$ & 217 \\
\hline Total & 85 & 132 & 0.0001 \\
\hline
\end{tabular}




\section{Relationship between deaths due to poisoning with age group}

The association between age group and death due to poisoning was found to be higher in between 0-39 years with $62.35 \%$ and was statistically significant $(\mathrm{p}=0.0001)$. The results are shown in Table 5.

\section{Discussion}

Birth and death are the two most important events in the life of any individual, as the person's existence starts at the moment of birth and ceases at the moment of death. A person has legal existence between the recorded timings of birth and death. Apart from this legal importance, recording of births and deaths creates vital basic data about a population group [6].

This study signifies that a total of 217 death cases, 39\%, $15 \%, 8 \%, 26 \%, 1 \%, 7 \%$ and $4 \%$ were due to poisoning, drowning, current, hanging, thundering, fall from height and burn respectively. Similarly, a study conducted at Bharatpur Hospital, Chitwan, Nepal in 2003 by Prasad and Prasad, of total 229 autopsy cases, 47\%, 20\%, 17\%, 7\%, 4\%, 3\%, 2\% death cases were due to RTA, hanging, poisoning, drowning, fire arm injury, animal bite and burns respectively [7] which is not similar to this study.

This study highlights the highest number of death cases were found in male than female below 19 years age group of $35.02 \%$ followed between 20-39 years with $34.56 \%$ and was statistically insignificant $(\mathrm{p}=0.416)$. A similar finding was also obtained in the study conducted by Prasad and Prasad in 2003 that male had more death than female [7] which is in accordance with this study.

Poison is substance capable of producing damage or dysfunction in the body by its chemical activity which can enter the body by various routes to produce local and systemic effects acting adversely or deleteriously on the body [8]. Poisoning is a common means in both completed and attempted suicide [9]. Trends of poisoning had been constantly changing throughout the world with advent of new agents leading cause of death from injuries in developed and developing countries, as reported by the Centers for Disease Control and Prevention and National Center for Health Statistics [10].

The present study revealed that most of the death cases due to poisoning were $39.17 \%$ of which $33.82 \%$ were male and $48.14 \%$ were female. Similar findings were also obtained in the study conducted by Maskey et al. [9] 2012 reported 56.2\% were males while $43.8 \%$ were females. Ghimere et al. [11] noticed significant increase in percentage of male poisoning cases from $31.4 \%$ to $42.7 \%$. Similar study done in Dharan showed male cases was more than females [12] which is in accordance with this study.

But in the study conducted by Khadka and Ale in 2005 found female death slightly more than male due to poisoning. Similarly,
Bajracharya et al. [13] BP in 2008 reported from Bir hospital, female had very high preponderance. In another study carried in Turkey, females (59.5\%) died more than males (40.5\%) [14]. Similar findings were also obtained in the study conducted by Pokhrel \& Kafle et al. [15-17] which is not in accord with the study conducted by Khadka [18]. This may be because of socioeconomic status of the country, frustration, family conflict, job problem, easy availability of the pesticides, drugs, and easy approachable placement of household chemicals/medicines at home. Drug abuse, overdose and accidental ingestion may be the other cause.

Death in suicidal hanging is secondary to hypoxia and cerebral ischemia due to compression of airway and major blood vessels of neck caused by ligature applied round the neck and the force of compression being the body weight [19-23]. Mainly respiratory and neurological complications such as pulmonary or neurogenic edema resulting in post-obstructive pulmonary distress, aspiration pneumonitis, ARDS, seizures, hypotension, neck vessel compression and cerebral hypoxia and multi organ failure can arise as fatal complications of hanging [22-28].

This study also highlights that the second cause of death was hanging with $26.26 \%$ where male $(23.52 \%)$ was found more than female (30.86\%). Similar findings were also obtained in the study carried out by Saiyed and Modi at Vadilal Sarabhai General Hospital, Ahmedabad in 2013 where males (62.16\%) outnumbered the females $37.83 \%$ in hanging [29] which is in accordance with study. Hanging were more common among males due to increasing depression among young people and activeness of male in the society and female being more accommodative to changing mentally and traumatic circumstances leading to suicidal attempts. But, in the study conducted at BPKIHS, Dharan by Pradhan et al. [30], hanging was slightly more preferred by females $(47 \%)$. This findings was also shown by the studies carried out by Kafle et al. [19] in Tribhuvan University Teaching Hospital, Urmila et al. [31] in Nepal Medical College, Pratap et al. [32] in Tribhuvan University Teaching Hospital which differs from this study.

Drowning in order to commit suicide is a rather rare, but important forensic manifestation and has to be distinguished from accidents, homicides and natural death in water [33]. It is the process of experiencing respiratory impairment from immersion in liquid which outcomes are classified as death, morbidity and no morbidity" [34].

This study reflects that the maximum number of the death cases were found in age below 19 years due to drowning (71.57\%) followed by age group 20 -39 years due to poisoning $41.17 \%$ which is almost similar to the findings of Bajracharya et al. [13]. Drowning is the leading cause of injury death to children aged 1-14 years in China [34,35]. In Bangladesh, 20\% of all deaths in children aged 1-4 years are due to drowning [24]. But, the study carried by Maskey et al. [9] at Manipal Teaching Hospital, Pokhara, Nepal found the maximum percentage $43.1 \%$ 
of poisoning cases occurred in younger age group 15-24 years which is not in concurred with the present study. This study suggests males have higher drowning rates than females which may be due to increased exposure to water and riskier behaviors such as swimming alone, drinking alcohol before swimming and boating. Due to the negligency of parents in care of children mostly in playing age groups are the another reason for the drowning cases. Most of the death cases in youngsters having love affairs lead to frustation and depression which may be the another reason for the death due to easily available poisons.

The highest number of death cases were reported in July to September 76 (35.02\%) followed by April to June 55 (25.34\%) due to poisoning of $33(38.82 \%)$ and 24 (28.23\%) respectively. Haloi et al. [10] conducted a similar type of study in the district of Kamrup, Assam also reported the highest cases (44.79\%) of poisoning took place in summer which is in accordance with this study. This may be due to active agricultural activities in these months when pesticide and insecticide are extensively used.

The association between age group and death due to poisoning was found to be higher in between 0-39 years with $62.35 \%$ and was statistically significant $(p=0.0001)$ which is in accordance with the study conducted by Haloi et al. [10]. The males lead a more stressful life than female due to family, job responsibilities, social burdens and unusual pressures during the lifetime.

\section{Conclusion}

It is important to know the nature and severity of poisoning in order to take prompt appropriate treatment to save life and reduce morbidity and mortality. The present study concludes that major cause of deaths were poisoning, hanging and drowning. Male poisoning cases were found higher than female. The highest number of death cases was reported in the age group below 19 years due to drowning. Swimming programs should be promoted for primary school children. Swimming and water-safety skills are associated with significant reductions in drowning fatalities. Government should develop criteria of existing laws in relation to toxic substances like pesticide and insecticide should be incorporated to erase the loopholes for their production, distribution, sale, storage and application.

\section{Acknowledgement}

Authors wish to acknowledge Medical Suprintendent of Janakpur Zonal Hospital, Janakpur and Janaki Medical College, Janakpur for their reliable support during the completion of this study.

\section{References}

1. Dolinak D, Matshes EW, Lew EO (2005) Forensic Pathology: Principles and Practice. Elsevier Academic Press pp: 663.

2. Srivastava PC, Shikha Saxena S and Sahai MKB (2009) Medical Certification of cause of death. Internet J Med Update 4(1): 56-58.
3. Committee for the Workshop on the Medicolegal Death Investigation System (2003) Medicolegal Death Investigation System Workshop Summary. The National Academy Press, USA.

4. WHO Report (2002) Reducing Risks: Promoting Healthy Life. World Health Organization, Europe.

5. Suvedi BK (2007) Of what diseases are Nepalese people dying? Kathmandu Univ Med J (KUMJ) 5-1(17): 121-123.

6. Kotabagi Col RB, Chaturvedi Col RK, Banerjee Col A (2004) Medical Certification of Cause of Death. MJAFI 60(3): 261-272.

7. Prasad BK, Prasad C (2003) Road traffic accident (RTA) as major killer: A report on medicolegal autopsies in Bharatpur hospital. Kathmandu University Med J 1(1): 34-35.

8. Linden CH, Burns MJ, Mycyk MB (2008) Poisoning, drug overdose and envenomation. In: Fauci AS (ed), Harrison's Principles of Internal Medicine. McGraw-Hill, USA, pp: 2741-2748.

9. Maskey A, Parajuli M, Kohli SC, Baral S, Basnet S, et al. (2012) Scenario of Poisoning Cases in Adults Admitted in Manipal Teaching Hospital, Pokhara, Nepal. Nepal J Med Sci 1(1): 23-26.

10. Haloi M, Haloi DM, Patowary A (2013) Death due to Poisoning in District of Kamrup, Assam: A Medico-legal Study. J Indian Acad Forensic Med 35 (1).

11. Chakrabarti K1, Devkota KC (2001) Retrospective study of poisoning cases admitted in Nepal Medical College Teaching Hospital. Nep Med Col J 3: 101-105.

12. Gupta SK, Joshi MP (2001) Pesticide poisoning cases attending five major hospital of Nepal. J Nep Med Assoc 41:447-56.

13. Bajracharya MR, Manandhar K, Deo KK (2008) Age and gender distribution in deliberate self poisoning Cases PMJN 8: 44-49.

14. Yurumez Y, Durukan P, Yavuz Y, Ikizceli I, Avsarogullari L, et al (2007) Acute organophosphate poisoning in university hospital emergency room patient. Intern Med 46(13): 965-969.

15. Pokhrel N, Gurung CK (1987) A study of poison cases recorded in Bir hospital over four years. J Inst Med 9: 29-34.

16. Kafle KK (1989) Poisoning cases at T.U. Teaching hospital. J Inst Med 11: 297-301.

17. Rauniyar GP (1999) Retrospective Analysis of profile of acute poisoning case in a tertiary care hospital in eastern Nepal: A four year data base from 1994 to 1997. J Nep Med Assoc 38: 23-8.

18. Khadka SB and Ale SB (2005) A study of poisoning cases in emergency Kathmandu Medical College Teaching Hospital. Kathmandu University Med J 3(4): 388-391.

19. Vij K (2001) Textbook of Forensic Medicine, Principles and Practice (1 $1^{\text {st }}$ edn.). Churchill Livingstone Pvt, India, pp: 62.

20. Kafle KK, Kumar G (1992) Organophosphorous - commonest poisoning agent. Journal of Institute of Med 14: 228-233.

21. Parikh CK (1990) Text Book of Medical Jurisprudence \& Toxicology $\left(5^{\text {th }}\right.$ edn). CBS Publishers. Deaths from Asphyxia - Hanging, pp: 186-194.

22. Modi JP (2002) Medical Jurisprudence \& Toxicology (22 $2^{\text {nd }}$ edn). LexisNexis Butterworths, Deaths from Asphyxia - Hanging, pp: 251260.

23. Knight B (1996) Forensic Pathology ( $\left.2^{\text {nd }} e d n\right)$. Oxford University Press, USA, pp: 345-360.

24. Nair S, Jacob J, Aaron S, Thomas M, Joseph M, et al. (2009) Pulmonary distress following attempted suicidal hanging. Indian J Med Sci 63(2): 53-57. 
25. Fischman CM, Goldsmith MS, Gardner LB (1977) Suicidal hanging an association with the adult respiratory distress syndrome. Chest 71(2): 225-227.

26. Digeronimo RJ, Mayes TC (1994) Near-hanging injury in childhood: A literature review and report of three cases. Pediatr Emerg Care 10(3): 150-156.

27. Kaki A, Crosby ET, Lui AC (1997) Airway and respiratory management following non-lethal hanging. Can J Anaesth 44(4): 445-450.

28. Hoff BH (1978) Multiple organ failure after near-hanging: A case report. Crit Care Med 6(6): 366-369.

29. Saiyed MZG, Modi KA (2013) Retrospective Study of Postmortem Cases of Hanging - A Method of Suicide. NHL Journal of Medical Sci 2(2): 4850 .

30. Pradhan A, Tripathi CB, Mandal BK, Karn A, Subedi ND (2012) Suicide: Attempts Methods and Causes in Cases Brought for Autopsy in BPKIHS, Dharan. J Forensic Res 3(9): 1-3

This work is licensed under Creative

Commons Attribution 4.0 License

DOI: $10.19080 / C T B E B .2017 .02 .555600$
31. Urmila B, Bahadur SJ, Madhusudan S (2001) Study of Acute poisoning in Nepal Medical College Teaching Hospital. NMCJ 2(2): 83-85.

32. Narayan PP, Prakash K (1997) Poisoning cases at TUTH Emergency-A one-year review. Journal of the Institute of Medicine 19: 18-24

33. Statistisches Bundesamt (2013) Todesursachen in Deutschland 2011 Statistisches Bundesamt, Germany 2013.

34. WHO (1992) International statistical classification of diseases and related health problems, Tenth revision. World Health Organization, Geneva.

35. Dimaio VI and Dimaio D (2001) Forensic Pathology ( $2^{\text {nd }}$ edn). CRC Press, USA, pp: 245-325.

\section{Your next submission with Juniper Publishers} will reach you the below assets

- Quality Editorial service

- Swift Peer Review

- Reprints availability

- E-prints Service

- Manuscript Podcast for convenient understanding

- Global attainment for your research

- Manuscript accessibility in different formats

( Pdf, E-pub, Full Text, Audio)

- Unceasing customer service

Track the below URL for one-step submission https://juniperpublishers.com/online-submission.php 